June 17, 2008, Manuscript \#05079

\title{
Intermittent Water Supplies: \\ Challenges and Opportunities for Residential Water Users in Jordan
}

\author{
David E. Rosenberg, Member IWRA, Utah State University, USA, Samer Talozi, \\ Jordan University of Science and Technology, Jordan, and Jay R. Lund, Member IWRA, \\ University of California, Davis, USA
}

\begin{abstract}
Intermittent access to improved urban water supplies is a large and expanding global problem. This paper describes 16 supply enhancement and 23 demand management actions available to urban residential water users in Jordan to cope with intermittent supplies. We characterize actions by implementation, costs, and water quantities and qualities acquired or conserved. This effort systematically identifies potential options prior to detailed study and shows that water users have significant capacity to affect demand. We suggest several methods to evaluate options and highlight the need to include local water management decisions in integrated water resources management and planning at utility and regional scales.
\end{abstract}

Keywords: scarcity, resource, shortage, domestic, household, Jordan

\section{INTRODUCTION}

Over a billion people have limited or intermittent access to improved water supplies characterized by long distances to sources, frequent and regular service disruption, and increased costs. Intermittent service is often linked to water-borne diseases, uncertain and inadequate sanitation services, and environmental degradation. Intermittent service has many causes, including rationing to meet demands; polluted sources; inadequate storage, treatment, or distribution systems; or population growth exceeding the rate of new water resources and infrastructure development (Thompson et al. 2001). 
June 17, 2008, Manuscript \#05079

Considerable integrated water resources management (IWRM) work has focused on redressing causes of scarce water resources with efforts typically focused at transboundary, national, basin, or water utility scales (Dziegielewski et al. 1992; Fisher et al. 2005; Scott et al. 2003; Wilchfort and Lund 1997; Wolf and Murakami 1995). The starting point is to identify a wide variety of actions that increase supplies, improve qualities, decrease demand, or alter demand timing to improve system performance. Then characterize actions by costs, benefits, and quantities and qualities of water provided or conserved. Finally, use systems analysis to develop a mix of cost-effective and waterefficient actions that improve service levels and reliabilities given physical and institutional constraints.

This paper describes many water supply enhancement and conservation actions available to urban residential water users facing service disruptions in Jordan (Table 1) and discusses how users have significant ability to regulate system-wide demands. User actions are characterized by implementation, cost, water volume gained or conserved, and affected water quality. Jordan is a relevant case as water is generally available through the distribution network only 12 to 60 hours per week (Abu-Shams and Rabadi 2003), most households desire improved supply access, and the government is considering cityand national conservation efforts plus mega-supply projects to improve water availability. Systematically identifying and characterizing potential water user actions is an important first step prior to more detailed modeling, analysis, and planning at household, city, and regional scales. 
June 17, 2008, Manuscript \#05079

\section{GLOBAL SCOPE OF INTERMITTENT WATER SERVICE}

Approximately 82\% of the world's people have access to improved water service with some 816 million persons acquiring access since the 1990 assessment (WHO and UNICEF 2000). Here, “improved service” means a household connection, public standpipe, borehole, or protected spring, dug well, or rainwater catchments. However, the assessment did not consider the distance to the improved source nor the hours per day (or per week) that water is available. Many populations worldwide have access to improved water sources for less than 12 hours per day (Table 2).

Table 2 is only a partial listing and excludes many large countries for which data are not readily available. Table 2 also reports average water availabilities for cities and neglects inequities within a city between neighborhoods or apartments in buildings. The potential water quality, public safety, economic loss, public nuisance, and large number of persons affected make intermittent water supplies a major global problem.

\section{URBAN RESIDENTIAL WATER USE AND SERVICE IN JORDAN}

As seen in Table 2, Jordan has one of the least frequent water availabilities. Jordan's annual consumption of 1 BCM per year far surpasses annual renewable freshwater surface and groundwater supplies of $850 \mathrm{MCM} /$ year (groundwater overdraft covers the deficit). Water consumption is split among agricultural $69 \%$, urban $27 \%$, and industrial uses 4\% (Alkhaddar et al. 2005). Most of Jordan's population of 5.4 million persons (2004) reside in cities such as Amman, Zarka, and Irbid where more than $92 \%$ of the population has access to piped water in their house. These demographics mean that although water availability averages approximately $167 \mathrm{~m}^{3}$ per capita per year, water use is only 22 to $36 \mathrm{~m}^{3}$ per capita per year (60 - 100 liters per capita per day) (Scott et al. 2003). This level is just at the WHO minimum water use requirements for health and 
June 17, 2008, Manuscript \#05079

hygiene and nearly $1 / 10^{\text {th }}$ of water use in the USA or Australia. Low per-capita water use is enforced through strict availability rationing, with water commonly distributed through the municipal network for 12 to 60 hours per week (Abu-Shams and Rabadi 2003). Scarcities will likely worsen as Jordan's population grows at 2 to 3\% per year.

\section{Municipal Water Service to Residential Customers}

Municipal piped water is the primary supply for most Jordanian households. In Amman, the French/Jordanian consortium Suez Lyonnaise des Euax/Arabtech Jardaneh and Montgomery Watson (LEMA) held the management contract to provide water service until 2006 and divided the network into approximately 250 distribution zones, rotating the days and times water was available in each zone.

Amman households pay a one-time fee to connect to the distribution network through a lateral monitored by a water meter and a connection surcharge for each square meter of floor area above $150 \mathrm{~m}^{2}$. Water use is billed at three-month intervals. Metered rate varied from JD 0.18 to 2.34 per $\mathrm{m}^{3}$ (JD $1.00=$ \$US 1.41 in 2004, exchange rate stable since 1995) in 4 increasing price blocks (see Table 3 for summaries; Rosenberg (2008)). Rates include all water and sewage charges, meter reading and pumping fees. Outside Amman, households pay a JD 200 one-time connection fee, the same surcharge for excess floor area, and lower metered rates.

\section{Household Water Infrastructure and Uses}

Figure 1 shows a Jordanian household’s typical water sources and uses. Because municipal supply is intermittent and rationed, most households store water in roof $\operatorname{tank}(\mathrm{s})$. Households may also store water in ground $\operatorname{tank}(\mathrm{s})$ or a cistern. The roof tank is the primary means of continuous, gravity-flow distribution to water fixtures in and 
June 17, 2008, Manuscript \#05079

around the house (often excluding drinking water). Household water pressure depends on the elevation difference between the roof tank and the point of use. Typically, heads range from 3 to 18 meters.

When roof and other storage tanks empty before water is next available through the municipal network, households face water scarcity. Scarcity also arises when municipal water service does not resume as expected. In these situations, households purchase water from secondary sources delivered to the house on demand. Alternatively, the household can reduce water use. This paper identifies and describes the many potential household actions to prepare for and cope with scarcity. First, we list methods used to identify and learn about household water management actions. Then, we describe the actions.

\section{RESEARCH AND DATA COLLECTION METHODS}

56 informal interviews with tradesmen, 34 semi-structured surveys and written questionnaires with heads of households, municipal water service billing records for 21 households surveyed, and prior empirical work (Ahmed 2004; Bino et al. 2000; CSBE 2004; Faruqui and Al-Jayyousi 2002; Fitzgerald 2005; IdRC 2004; Iskandarani 2002; WEPIA 2000; Whalen and Al-Saudi 1998) were used to identify potential household water management actions, costs, water quantities, and household perceptions regarding potential actions. We used a "snow-ball” sampling technique (Blaikie 2000, p. 205-6) to identify interviewees and respondents. The diversity, number, and method to identify interviewees and respondents was not intended to randomly sample Jordanian households. Rather, it served to create a wide-ranging inventory of household water management activities. Interviews, surveys, and questionnaires were conducted principally in Arabic in and outside Amman between June and October 2004 (Rosenberg 2008, Chapter 2). 
June 17, 2008, Manuscript \#05079

\section{MANAGEMENT ACTIONS AVAILABLE TO JORDANIAN HOUSEHOLDS}

Tables 3 and 4 summarize 16 supply enhancement and 23 demand management actions available to Jordanian households. Long-term actions require a (generally large) capital investment and establish infrastructure for supply and demand management. These actions must be taken well before any actual supply provision or demand reduction. Short-term actions can be implemented or purchased when needed and provide flexibility to cope with events as they occur. Summaries for each management action highlight implementation, financial costs, effective volume of water gained or conserved, and the type of use or water quality affected.

We report financial costs as the average, highest, and lowest price quotes from interviews and surveys. We report the effective quantity as either a (i) number (i.e., storage tank volume), (ii) range based on physical upper and lower limits (i.e., total capacity to store water and draw water from storage), or (iii) the estimated $10^{\text {th }}$ and $90^{\text {th }}$ percentiles of the effectiveness distribution derived for Amman households (Rosenberg 2007).

\section{Supply Enhancement Actions}

\section{Long-term supply actions}

Long-term actions establish the infrastructure of water supply.

Connect to network. Households pay a one-time fee to access the piped water supply with low unit cost. Households differ in their assessments of municipal water quality. Nearly all households use network water indoors for washing and hygiene and outdoors to irrigate landscaping or wash cars. In Amman, only a few households use municipal water untreated for drinking or cooking. Outside of Amman, the percentage is larger. 
June 17, 2008, Manuscript \#05079

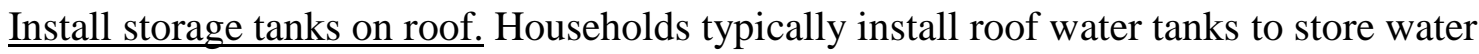
when it is available through the municipal network or purchased from a private tanker truck. Roof tanks are either plastic or of welded thin galvanized metal, from 1 to $2 \mathrm{~m}^{3}$, and purchased at local metal shops. Price depends on metal thickness, workmanship quality, and shop owner's flexibility to negotiate. Households use water stored in a tank and municipal water similarly.

Install storage tank at ground level. Homeowners frequently install additional groundlevel water tanks to store more water when it is available. Ground tanks are identical to roof tanks in construction and cost, but require a 1 to 2 hp pump to transfer water to roof tank(s). Households use water stored in a ground tank and municipal water similarly.

Install cistern. Homeowners can install cisterns or underground tanks larger than $13 \mathrm{~m}^{3}$ to store rainwater or municipal water. In Jordan, cisterns are either pre-existing plaster-lined excavations in the underlying limestone [a 3000-year old technology (Wahlin 1995)] or concrete-lined excavations underneath the car-park or part of the foundation made when a house is constructed (Ahmed 2004; Whalen and Al-Saudi 1998). The Jordanian Water Code mandates each new residential building to have a water cistern of at least $6 \mathrm{~m}^{3}$, but code enforcement can be lax. Retrieving water from a cistern requires a pump. Cistern water can serve all household water uses. Some households maintain that rainwater is of superior quality and use cistern water exclusively for drinking. Other households find rainwater quality inadequate and use cistern water exclusively outdoors to irrigate landscaping or wash cars.

Collect rainwater. Homeowners can collect rainwater from the roof into a ground tank or cistern. Collecting rainwater requires (a) cleaning the roof, (b) installing pipe from the downspout to storage, and (c) adding a first-flush valve to bypass matter built up through 
the dry season and entrained in runoff from the first winter storm. The annual volume of rainwater collected depends on winter season precipitation, roof surface area, number of families sharing the roof, storage capacity, and sequence of rainfall and water consumption during the rainy season. Households use rainwater and water stored in cisterns similarly.

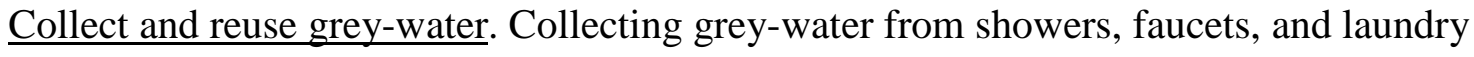
machines and reusing it outdoors to irrigate landscaping or olive, fruit, or nut trees is expanding in Jordan (Bino et al. 2000; CSBE 2004; Faruqui and Al-Jayyousi 2002). Some households also reuse water indoors to flush toilets or wash floors.

Installation costs depend on plumbing retrofits and a household's perceived need for treatment. Estimates range from zero (disconnect sink drains and collect water in buckets) to $19 \mathrm{JD}$ (simple basins or strainers to settle or separate particulates) on up to 150 JD (two- or four-barrel anaerobic digesters for secondary treatment).

Installing a dual grey-water piping system increases plumbing construction costs by only $33 \%$ or 61 JD per bathroom when done during home construction. Pipes are easily laid next to potable and black-water pipes before cement floors are poured. Retrofitting dual pipes requires excavating cement floors and is much more expensive. Reusing grey-water can also help rural households without sewer connections avoid most of the $200-400 \mathrm{JD}$ cost to excavate upwards of $60 \mathrm{~m}^{3}$ of ground for a septic tank. Upwards of $50 \%$ of a households' water budget may constitute grey-water suitable for reuse. However, the volume collected depends on household size, flow rates of existing water appliances, water use practices, and behaviors. 
June 17, 2008, Manuscript \#05079

Drill well. Homeowners can hire a contractor to install a well with costs up to 60 JD per meter drilled plus 1750 JD for licensing. Depths to ground water generally exceed 60 meters. Although groundwater basins in Jordan are over-drafted and the government no longer issues well permits to households or small farmers, illegal well drilling and use continue. Well drilling is only available to homeowners who live in rural areas. Households apply well water for all uses.

Install in-home water treatment. Homeowners can purchase water treatment units (filters, reverse-osmosis membranes, and ultraviolet disinfection lights) throughout Amman that fit under the kitchen sink and produce up to 180 liters per day of treated water. Price excludes additional annual operational and maintenance costs to replace filters, membranes, and lamps. Most units generate saline waste streams and require raw water inputs up to four times the volume of treated water generated. This treated water is an expensive but reliably high quality source used exclusively for drinking and cooking.

\section{Short-term supply options}

Short-term supply actions can be implemented when needed or in response to particular events. They require no advance planning (unless conditioned on long-term infrastructure discussed above).

Take delivery through public network. The Amman water utility charges residential users with established connections for their metered water consumption quarterly by the prices in Table 3. This water serves most uses but is only available intermittently.

Buy from water store. Since 1998, more than 180 retail outlets in Amman are registered and licensed with the Ministry of Health to sell potable water (Fitzgerald 2005). Homeowners telephone a store to request delivery. Stores treat source water from the 
June 17, 2008, Manuscript \#05079

network or private tanker trucks with large-scale water softeners, filters, reverse-osmosis and ultraviolet light. They bottle treated water in 10 or 20-liter plastic jugs for delivery upon request. Each store serves from a hundred to a thousand customers. Water store purchases are an expensive but trusted, high quality source used exclusively for drinking or cooking.

Buy bottled water. Homeowners can readily buy mineral or spring water marketed under brands such as Furat, Ghadeer, and Nivea in 1.5- or 2-liter plastic bottles at supermarkets and mini-markets throughout Jordan. Bottled water is an expensive but trusted, high quality source used for drinking or cooking.

Buy water from private vendor. Homeowners can contract with private water tanker truck drivers to deliver bulk water supplies to the house, for filling roof or ground tanks, or a cistern. Truck capacities range from 6 to $20 \mathrm{~m}^{3}$. Drivers often fill their tankers at licensed governmental wells twenty to thirty km outside the city for $5 \mathrm{JD}$, congregate at specific locations, and wait for customers. Congregation points become spot markets for water sales where sale price fluctuates depending on the season, customer demand, and negotiation flexibility of the driver and buyer. Drivers generally require sales of at least 3 or $4 \mathrm{~m}^{3}$ and force families with small tanks to coordinate purchases. Tanker water is an expensive, readily-available source of variable water quality. Most households use this water indoors for washing and hygiene, or outdoors to irrigate or wash cars.

Borrow water from neighbors. Homeowners can borrow water from the roof tanks of neighbors or fill a bucket to temporarily cover essential indoor washing or hygiene uses like toilet flushing. Water is generally borrowed or lent without financial charge as an obligation to families in need. 
June 17, 2008, Manuscript \#05079

Draw water from well. Rural homeowners who have installed a well may draw water from it. Operation costs are for diesel or electricity to run the pump and depend on the depth to groundwater and quantity of water drawn. No further data is available since no urban, residential households surveyed report having or using a well.

Treat water inside home for drinking. Homeowners can boil water on gas kitchen stoves to treat water to drink. This water is routinely served as tea or coffee. Preparation costs depend on fuel price ( 2 - 3 JD per tank), time tank lasts ( 1 - 4 months), fraction of time the stove is used to heat water as opposed to other cooking tasks ( 0.4 to 0.6 ), and daily quantity of water consumed (5 - 15 liters per day).

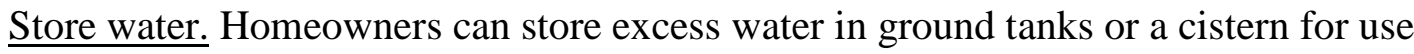
later. There is negligible cost when water is delivered by gravity. Quantity is limited by storage capacity and available sources. Quality depends on source (households tend not to consider storage as degrading quality; they clean cisterns annually).

Draw water from storage. Homeowners also pump water from storage to the roof for distribution and use during a crisis or when needed. Cost depends on the water volume drawn and pumping lift. Quantity is limited by water storage capacity. Quality depends on the original source (see store water above).

\section{Demand Management Actions}

Demand management actions reduce the quantity or alter the timing of household water use. Water volumes conserved vary among households and depend on many household geographic, demographic, technologic, and behavioral factors. 
June 17, 2008, Manuscript \#05079

No published information describes the effectiveness of demand management actions in Jordan and we did not measure effectiveness empirically. Instead, we report benchmark statistics from derived estimated distributions of effectiveness among Amman households (Rosenberg 2007). As many of the uncertain parameters influencing effectiveness and for which empirical data is available (Rosenberg 2008) are functionally multiplied together, effectiveness tends towards a lognormal distribution with significant skew towards a few households that can achieve large savings (Rosenberg 2007). Effectiveness ranges (Table 4 , column 6) are the estimated $10^{\text {th }}$ and $90^{\text {th }}$ percentiles of the effectiveness distribution among Amman households. Maximum coverage (column 7) indicates the percentage of households with effectiveness exceeding zero and suggests the potential market penetration rate. Below, we describe actions by implementation and affected water uses.

\section{Long-term demand management actions}

Long-term demand management actions represent infrastructure modifications and must be taken well in advance of reductions in household water use.

Install water saving devices. Homeowners can replace high-volume showerhead, faucet, or western toilets with water saving devices (WSDs) that maintain the quality of service but reduce the volume of water employed per use. Examples include installing faucet aerators on showerheads, kitchen faucets, or bath faucets, retrofitting western toilet tanks with dual-flush or adjustable water level mechanisms, or replacing western toilet tanks larger than 7 liters with smaller tanks. Retrofit appliances and parts are available at many stores in Amman. WSDs installed at Amman's largest institutional water users reduced water use by about 50\% (Tawarneh, personal communication, 2004). However, actual water savings depend on the flow rate of the new device, flow rate of the existing device, and frequency and duration of use. 
June 17, 2008, Manuscript \#05079

Install water-conserving laundry machine. Homeowners can purchase an efficient laundry machine to reduce laundry water use by up to $61 \%$ for semi-automatic (dual-basin) machines or 20\% for automatic machines (IdRC 2004). Several efficient models are available in appliance stores. Currently, customers pay little attention to water efficiency and scant information exists to identify water efficient models. Actual water savings depend on the reduction in machine water consumption, wash weight and frequency, and rinse behaviors (for semi-automatic machine owners). Households washing laundry in buckets or semi-automatic machines may increase water consumption when switching to an efficient automatic machine.

Install low-water consuming landscape. Homeowners can employ xeriscaping to reduce landscape water use. Costs and water savings depend on garden area, existing landscaping, and homeowner's priorities for shading, cover, seating areas, ornamental and food production, lawn areas, materials, and changes in irrigation practices. For example, a homeowner could hire a landscape architect for 1,000 to 1,500 JD to develop a low-water use landscape plan for a small garden area. The homeowner could then purchase the required ground cover, seedlings, and trees from local nurseries for 300 to 1,500 JD (CSBE 2004), including 3-weeks of labor costs.

Install drip irrigation system. Homeowners can install plastic drip irrigation systems (including piping, micro-sprayers, emitters, and drippers) in lieu of irrigating with hoses and furrows. Drip systems are sold at many garden and irrigation stores in and around Amman. Installation costs vary with landscaped area. Water savings depend on the landscaped area and watering times prior to and after installing the drip system. 
Install spray nozzle on hoses. Homeowners can install spray nozzles sold at gardening stores on outdoor hoses to reduce wastage while watering. Savings depend on the hose diameter, household water pressure, and frequency of hose use.

Install carpet on floors. Homeowners can install floor carpeting to avoid regular indoor floor washing with water. Installation costs depend on floor area.

Install pressure-reducing valve. Homeowners can install a pressure-reducing valve (PRV) to reduce household water pressure to between 5 to 10 meters of head (0.5 to $1.0 \mathrm{bar}$ ). PRVs reduce leakage and consumption for indoor washing and hygiene such as showering, dish, hand, and face washing (uses that depend more on time length of use than flow rate). PRVs most effectively reduce water use in multi-floored buildings with four or more floors between the roof storage tanks and point of use.

\section{Short-term demand management actions}

Households can implement short-term actions to immediately reduce water use.

Install bottles in toilet tanks. Homeowners can insert used, filled plastic bottles into western toilet tanks to reduce flush volume. Implementation costs are negligible. Alternatively, homeowners can lower the level of toilet flush mechanisms.

Find and fix leaks. Homeowners search for leaks and fix them when they are detected. Homeowners can hire a plumber. Water savings depend on household water pressure, leak size, and leak duration before repair.

Reduce irrigation to landscape. Homeowners can decrease landscape irrigation time per week. Financial costs are negligible and may even free time to pursue other activities. 
However, repeated stress irrigation can undermine plant productivity, reduce aesthetic values, damage, or kill plants. Effectiveness depends on the hose diameter, household water pressure, irrigation length and frequency.

Modify water use behaviors. Households can also temporarily modify water-use to reduce indoor consumption for washing and hygiene or outdoor use for irrigating and car washing as listed in Table 1. costs for these behavior changes are difficult to estimate. Yet, estimated water savings can be significant.

\section{DISCUSSION}

Households in Jordan can adopt a wide variety of water supply enhancement and demand management actions. Actions have varying time-scales for implementation, financial costs, water effectiveness, and affected qualities. Combining different short- and longterm actions gives households great flexibility to respond to service disruptions.

Action costs and effectiveness depend on perceived issues such as inconvenience or conformity with cultural norms plus many household-specific geographic, demographic, technologic, and behavioral factors. These factors include building location; house type; garden or livestock area; family size; household water pressure; lengths and frequencies of water appliance uses; their water use efficiencies; and efficiencies of WSDs. Households also may assess different lifetimes for long-term actions.

Some management actions are only available to households with specific classes of water uses. For example, only households with gardens can xeriscape, install drip irrigation, or spray nozzles on hoses to reduce outdoor demands. Likewise, only apartment owners with ground-level access can install a cistern or ground tank. Other households may find 
June 17, 2008, Manuscript \#05079

a management action achieves little or no water savings because of preexisting infrastructure. Maximum coverage (Table 4, column 7) estimates the percentage of Amman households likely to save water from a conservation action.

Effectiveness estimates assume households adopt a conservation action individually. Yet adopting one conservation action (faucet retrofits for example) may reduce water saved by other behavior changes (reduced wash time or partially opened faucet). More detailed systems analysis can help resolve interdependencies among actions and identify combinations of actions that cost-effectively respond to service disruption events. A systems perspective also can integrate physical and institutional constraints affecting user decisions and help study the effects on user decisions of increased network water availability such as continuous piped supply.

Further work should empirically verify estimated water savings and market penetration rates for conservation actions, investigate household tradeoffs for costs and risk tolerance to different levels of service or access, and aggregate effects of user choices on water use. These aggregate effects will have implications for IWRM at wider utility and national scales, particularly city and national conservation efforts and the planning, sizing, and timing of mega new-supply projects such as pipelines and desalination. For example, Jordanian government plans to expand Zai treatment plant capacity, bring the ZaraMa'een desalination project online, and build the Disi-Amman conveyer and Red-Dead Canal with hopes to move some or all of Amman towards continuous piped supply. Further, conservation efforts to reduce distribution system leaks, curtail illegal connections and non-revenue water losses, enact laws specifying water-related plumbing and building practices for new construction, introduce demand management concepts in schools, and promote WSDs. User choices and their effects can shape education and awareness campaigns, suggest rebate amounts or tax credits to motivate customers to 
adopt water conservation technologies, or highlight inefficient water use practices to change with technology development programs or plumbing code modifications. Identifying and characterizing potential water user actions is a key first step to successful IWRM at household (Rosenberg et al. 2007), city (Wilchfort and Lund 1997), and regional (Fisher et al. 2005; Rosenberg 2008) scales.

\section{CONCLUSIONS}

Intermittent water deliveries are a major global problem. In Jordan and other countries, water users can adopt a wide and complex range of supply enhancement and demand management actions to improve performance or better cope with local water service conditions. Actions involve different financial costs, inconveniences, water volumes gained or conserved, and associated water qualities. These characteristics can vary significantly among individual users. Users need only implement some actions for short time periods to respond to particular service disruptions or shortages whereas other actions require significant long-term capital investment and prior planning. Identifying and characterizing available options is important before water use efficiency evaluation (Dziegielewski et al. 1992) and systems analysis.

Individual water users make most water management decisions. These analyses can help identify cost-effective, water efficient actions, clarify interactions among potential management actions, develop strategies for individual water users, and summarize the aggregate affects of decentralized water user decisions. Understanding the aggregate effects of water user decisions is key to successful IWRM at utility, regional, and national scales. 
June 17, 2008, Manuscript \#05079

\section{ACKNOWLEDGEMENTS}

The authors thank Hani Abu Qdais for distributing the written questionnaire to his students and offering comments on an earlier draft. Dr. Rosenberg was supported by a National Science Foundation graduate research fellowship.

\section{ABOUT THE AUTHORS}

David Rosenberg is an Assistant Professor in the Dept. of Civil and Environmental Engineering at the Utah State University. His research uses systems analysis—simulation and optimization modeling and data management—-to study the engineering, economic, environmental, social and political aspects of water resources problems at household, water utility, and regional scales. He is reached by email at david.rosenberg@usu.edu.

Samer Tolozi is an Assistant Professor in the Biosystems Engineering Department at the Jordan University of Science and Technology, Irbid, Jordan. He specializes in bioenvironmental and irrigation engineering, agricultural water resources, demand management, and waste management for biological production systems.

Jay Lund is a Professor of Civil and Environmental Engineering at the University of California, Davis. He specializes in water and environmental engineering, management, and policy.

\section{REFERENCES}

Abu-Shams, I., and Rabadi, A. (2003). "The strategy of restructuring and rehabilitating the greater Amman water network." Water Resources Development, 19(2), 173183.

Asian Development Bank (ADB). (1997). "Second Water Utilities Data Book - Asian and Pacific Region." Asian Development Bank, Manila, Philippines. 
June 17, 2008, Manuscript \#05079

http://www.adb.org/Documents/Books/Second_Water_Utilities/default.asp

[Accessed on: January 18, 2005].

Ahmed, I. T. A. (2004). "Rainwater Harvesting in Amman." International water demand management conference, Dead Sea, Jordan, June 1, 2004.

Al-Ghamdi, A. S., and Gutub, S. A. (2002). "Estimation of leakage in the water distribution network of the Holy City of Makkah." Journal of Water Supply

Research and Technology-Aqua, 51(6), 343-349.

Alkhaddar, R. M., Sheehy, W. J. S., and Al-Ansari, N. (2005). "Jordan's Water Resources: Supply and Future Demand." Water International, 30(3), 294-303.

Bino, M., Al-Jayyousi, O., Sawan, J., Al-Beiruti, S., and Al-Makhamereh., S. (2000).

"Evaluation of Permaculture and Greywater Reuse Project in Tafila, Jordan: Final Report." Inter-Islamic Network on Water Resources Development and Management (INWRDAM) for the International Development Research Centre (IDRC), Ottawa, Ontario, Canada. http://www.inwrdam.org/page/158.

Blaikie, N. (2000). Designing Social Research: The Logic of Anticipation, Policy Press, Cambridge, MA.

Center for Study of the Built Environment (CSBE). (2004). "Greywater Reuse Project." Amman, Jordan. http://www.csbe.org/graywater/contents.htm [Accessed on: November 29, 2004].

Dziegielewski, B., Opitz, E. M., Kiefer, J. C., and Baumann, D. D. (1992). "Evaluation of urban water conservation programs: a procedures manual." California Urban Water Agencies. http://www.cuwcc.com/uploads/tech_docs/EvaluationOfUrbanWaterCnsvPrgms.p df.

Faruqui, N., and Al-Jayyousi, O. (2002). "Greywater reuse in urban agriculture for poverty alleviation - A case study in Jordan." Water International, 27(3), 387394.

Fisher, F. M., Huber-Lee, A., Amir, I., Arlosoroff, S., Eckstein, Z., Haddadin, M. J., Hamati, S. G., Jarrar, A. M., Jayyousi, A. F., Shamir, U., and Wesseling, H. (2005). Liquid Assets: An economic approach for water management and conflict resolution in the Middle East and beyond, Resources for the Future, Washington, D.C.

Fitzgerald, H. H. (2005). "Private Sector Participation in Water Provision: The Case of Amman, Jordan," MSc, University of Texas at Austin, Austin, TX.

Interdisciplinary Research Consultants (IdRC). (2004). "A Survey of Home Appliances and Toilets in the Jordanian Markets." Academy for Educational Development: Water Efficiency for Public Information and Action (WEPIA) Program, Amman, Jordan, $50 \mathrm{pp}$.

Iskandarani, M. (2002). "Economics of Household Water Security in Jordan." Development Economics and Policy, F. Heidhues and J. v. Braun, eds., Peter Lang, Frankfurt am Maim, 133.

Kyessi, A. G. (2005). "Community-based urban water management in fringe neighbourhoods: the case of Dar es Salaam, Tanzania." Habitat International, 29(1), 1-25.

Rosenberg, D. E. (2007). "Probabilistic Estimation of Water Conservation Effectiveness." Journal of Water Resources Planning and Management, 133(1), 39-49. 
Rosenberg, D. E. (2008). "Integrated Water Management and Modeling at Multiple Spatial Scales," PhD, University of California, Davis, Davis. http://cee.engr.ucdavis.edu/faculty/lund/students/RosenbergDissertation.pdf.

Rosenberg, D. E., Tarawneh, T., Abdel-Khaleq, R., and Lund, J. R. (2007). "Modeling Integrated Water-User Decisions in Intermittent Supply Systems." Water Resources Research, 43(7), W07425.10.1029/2006WR005340.

Scott, C. A., El-Haser, H., Hagan, R. E., and Hijazi, A. (2003). "Facing Water Scarcity in Jordan: Reuse, Demand Reduction, Energy, and Transboundary Approaches to Assure Future Water Supplies." Water International, 28(2), 209-216.

Soares, L. C. R. (2001). "Regional Report on the Evaluation 2000 in the Region of the Americas: Water Supply and Sanitation, Current Status and Prospects." Pan American Health Organization. http://www.cepis.opsoms.org/bvsaas/i/fulltext/infregio/infregio.pdf. [Accessed on: January 15, 2005].

Thompson, J., Porras, I. T., Tumwine, J. K., Mujwahuzi, M. R., Katui-Katua, M., Johnstone, N., and Wood, L. (2001). "Drawers of Water II: Summary." International Institute for Environment and Development, London. http://www.iied.org/sarl/dow/pdf/summary.pdf.

Tokajian, S., and Hashwa, F. (2003). "Water quality problems associated with intermittent water supply." Water Science and Technology, 47(3), 229-234.

Wahlin, L. (1995). "The Family Cistern: 3000 Years of Household Water Collection in Jordan." Third Nordic Conference on Middle Eastern Studies, Joensuu, Finland, 19-22 June 1995, 233-249.

Water Efficiency and Public Information for Action (WEPIA). (2000). "Assessment of Water Saving Devices Sector in Jordan." Amman, Jordan, 39 pp.

Whalen, M., and Al-Saudi, H. (1998). "Small Project Assistance Grant Proposal: Repairing Cisterns in Hisban, Jordan." U.S. Peace Corps-Jordan and United States Agency for International Development, Amman, Jordan.

World Health Organization and United Nations Children's Fund (WHO, and UNICEF). (2000). "Global Water Supply and Sanitation Assessment 2000 Report." Joint Monitoring Programme for Water Supply and Sanitation, Geneva: WHO and New York: UNICEF. http://www.who.int/docstore/water_sanitation_health/Globassessment/GlobalTO C.htm [Accessed on: January 15, 2005].

Wilchfort, O., and Lund, J. R. (1997). "Shortage management modeling for urban water supply systems." Journal of Water Resources Planning and Management, 123(4), 250-258.

Wolf, A. T., and Murakami, M. (1995). "Techno-political decision making for water resources development: the Jordan River watershed." Water Resources Development, 11(2), 147-161.

\section{FIGURE CAPTIONS}

Figure 1. Schematic of Household Water Sources and Uses in Jordan 
Table 1. Potential Water Management Actions for Urban Water Users

\begin{tabular}{|c|c|c|}
\hline \multirow{2}{*}{ Stage } & \multicolumn{2}{|c|}{ Water Management Actions } \\
\hline & Supply Enhancement & Demand Management \\
\hline $\begin{array}{l}\text { Long-term } \\
\text { Actions }\end{array}$ & $\begin{array}{l}\text { - Develop new supplies } \\
\text { - Establish network connection } \\
\text { - Install rainwater collection system } \\
\text { - Drill well } \\
\text { - Install local storage } \\
\text { - Roof tanks } \\
\text { - Ground tanks } \\
\text { - Cisterns (underground storage) } \\
\text { - Install grey-water collection system } \\
\text { - Install in-home drinking quality water treatment }\end{array}$ & $\begin{array}{l}\text { - Install water efficient appliances } \\
\text { - Showerheads } \\
\text { - Kitchen or bath faucets } \\
\text { - Low flush toilets or dual flush mechanisms } \\
\text { - Auto- or semi-automatic laundry machines } \\
\text { - Drip irrigation system } \\
\text { - Spray nozzles on outdoor hoses } \\
\text { - Reduce water use } \\
\text { - Install low water-consuming landscape or crops } \\
\text { - Pressure reducing valve } \\
\text { - Install permanent carpets in rooms }\end{array}$ \\
\hline $\begin{array}{c}\text { Short-term } \\
\text { Actions }\end{array}$ & $\begin{array}{l}\text { - Access supplies } \\
\text { - Take delivery through public network } \\
\text { - Buy water from private vendor (tanker truck) } \\
\text { - Buy drinking quality water from a store } \\
\text { - Buy bottled water } \\
\text { - Drink collected rainwater } \\
\text { - Borrow water from a neighbor } \\
\text { - Draw water from well } \\
\text { - Store or draw water from local storage } \\
\text { - Improve quality } \\
\text { - Treat water inside home for drinking } \\
\text { - Boil water } \\
\text { - Collect, treat and apply grey-water to landscaping }\end{array}$ & $\begin{array}{l}\text { - Insert bottles or bags in toilet tank } \\
\text { - Find and fix leaks } \\
\text { - Modify water use behaviors } \\
\text { - Stress irrigate landscape or crops } \\
\text { - Sweep floors rather than wash them } \\
\text { - Turn off faucets while washing, brushing teeth, } \\
\text { shaving, or soaping up in the shower } \\
\text { - Wash car with bucket or at a gas station } \\
\text { - Partially open faucet } \\
\text { - Reduce laundry-washing frequency } \\
\text { - Reduce shower-taking frequency } \\
\text { - Reduce shower length }\end{array}$ \\
\hline
\end{tabular}


Table 2. Availability of Improved Water Services in Selected Cities and Countries

\begin{tabular}{|c|c|c|c|c|c|}
\hline City, Country & Year & $\begin{array}{l}\text { Population } \\
\text { (millions) }\end{array}$ & $\begin{array}{l}\text { Pop. with } \\
\text { Improved } \\
\text { Service } \\
(\%)\end{array}$ & Availability & Source \\
\hline Amman, Jordan & 2003 & 2.2 & 92 & 12-60 hrs/wk & Abu-Shams and Rabadi (2003) \\
\hline Bandung, Indonesia & 1995 & 2.2 & 42 & 6 hrs/day & ADB (1997) \\
\hline Cebu, Philippines & 1995 & 1.2 & 23 & 18 hrs/day & ADB (1997) \\
\hline Chennai, India & 1995 & 4.4 & 97 & 4 hrs/day & ADB (1997) \\
\hline Cuba (entire country) & 1998 & 11.1 & 93 & 12 hrs/day & Soares (2001) \\
\hline Dar es Salam, Tanzania & 2005 & 3.0 & 30 & 24-72 hrs/wk & Kyessi (2005) \\
\hline Delhi, India & 1997 & 10.8 & 86 & 4 hrs/day & ADB (1997) \\
\hline Faisalabad, Pakistan & 1996 & 1.8 & 60 & 7 hrs/day & ADB (1997) \\
\hline Guatemala (entire country) & 1998 & 9.0 & 80 & 6-12 hrs/day & Soares (2001) \\
\hline Haiti (entire country) & 1998 & 7.7 & 46 & $6 \mathrm{hrs} /$ day & Soares (2001) \\
\hline Honduras (entire country) & 1998 & 6.0 & 81 & 6 hrs/day & Soares (2001) \\
\hline Karachi, Pakistan & 1996 & 11.5 & 70 & 1-4 hrs/day & ADB (1997) \\
\hline Kathmandu, Nepal & 1995 & 0.9 & 81 & $6 \mathrm{hrs} /$ day & ADB (1997) \\
\hline Manila, Philippines & 1995 & 10.6 & 67 & 17 hrs/day & ADB (1997) \\
\hline Mekkah, Saudi Arabia & 2002 & 1.2 & 70 & Intermittently & Al-Ghamdi and Gutub (2002) \\
\hline Mumbai, India & 1996 & 10.3 & 100 & 5 hrs/day & ADB (1997) \\
\hline Naccache, Lebanon & 2003 & 0.03 & NA & 48 hrs/week & Tokajian and Hashwa (2003) \\
\hline Peru (entire country) & 1998 & 24.8 & 75 & 14 hrs/day & Soares (2001) \\
\hline Phnon Penh, Cambodia & 1996 & 0.8 & 83 & 12 hrs/day & ADB (1997) \\
\hline Saint Lucia (entire country) & 1998 & 0.15 & 98 & 10-12 hrs/day & Soares (2001) \\
\hline Thimphu, Phutan & 1996 & 0.03 & 93 & 12 hrs/day & ADB (1997) \\
\hline Yangon, Myanmar & 1995 & 3.2 & 60 & 12 hrs/day & ADB (1997) \\
\hline
\end{tabular}




\section{Table 3. Potential Actions to Enhance Household Water Supplies in Jordan}

\begin{tabular}{|c|c|c|c|c|c|c|c|c|c|}
\hline \multirow{2}{*}{$\begin{array}{l}\text { Water Management } \\
\text { Action }\end{array}$} & \multicolumn{4}{|c|}{ Price Quotes $^{\mathrm{a}}$} & \multirow{2}{*}{$\begin{array}{l}\text { Water } \\
\text { Volume } \\
\left(\mathrm{m}^{3}\right)\end{array}$} & \multirow[b]{2}{*}{ Uses $^{b}$} & \multirow{2}{*}{$\begin{array}{c}\text { Est. } \\
\text { lifespan }\end{array}$} & \multirow[b]{2}{*}{ Additional notes } & \multirow[b]{2}{*}{ Sources } \\
\hline & $\begin{array}{l}\text { Average } \\
\text { (JD) }\end{array}$ & $\begin{array}{l}\text { Highest } \\
\text { (JD) }\end{array}$ & $\begin{array}{l}\text { Lowest } \\
\text { (JD) }\end{array}$ & Num. & & & & & \\
\hline \multicolumn{10}{|l|}{ Long-term actions } \\
\hline \begin{tabular}{l|l|} 
Connect to network \\
\end{tabular} & 230. & -- & -- & 1 & -- & $\mathrm{D}, \mathrm{I}, \mathrm{O}$ & $\begin{array}{c}10+ \\
\text { years }\end{array}$ & $\begin{array}{l}\text { Plus } 1 \mathrm{JD} / \mathrm{m}^{2} \text { floor } \\
\text { area above } 150 \mathrm{~m}^{2}\end{array}$ & $\begin{array}{l}\text { LEMA (2004); WAJ } \\
(2004)\end{array}$ \\
\hline \multirow{2}{*}{$\begin{array}{l}\text { Install roof or } \\
\text { ground tanks }\end{array}$} & 74. & 95. & 65. & \multirow[t]{2}{*}{5} & 2 & \multirow[t]{2}{*}{$\mathrm{D}, \mathrm{I}, \mathrm{O}$} & 5 years & \multirow{2}{*}{$\begin{array}{l}\text { Volume per tank. Add } \\
\text { up to JD } 20 \text { to deliver }\end{array}$} & \multirow{2}{*}{$\begin{array}{l}\text { Interview retail store } \\
\text { owneres }\end{array}$} \\
\hline & 46. & 55. & 38. & & 1 & & 5 years & & \\
\hline Install cistern & 690. & 1,500 & 440. & 4 & 16 to 36 & $\mathrm{D}, \mathrm{I}, \mathrm{O}$ & $\begin{array}{l}10-20 \\
\text { years }\end{array}$ & Volume per cistern ${ }^{c}$. & $\begin{array}{l}\text { Whalen and Al-Saudi } \\
\text { (1998); Ahmad } \\
\text { (2004); Household } \\
\text { surveys }\end{array}$ \\
\hline Collect rainwater & 200. & 300. & 100. & 2 & $11.5-65.2$ & $\mathrm{D}, \mathrm{I}, \mathrm{O}$ & $\begin{array}{l}5-10 \\
\text { years }\end{array}$ & Volume per year ${ }^{\mathrm{d}}$. & $\begin{array}{l}\text { Ahmad (2004); JMD } \\
(2000)\end{array}$ \\
\hline $\begin{array}{l}\text { Install grey-water } \\
\text { collection and } \\
\text { treatment system }\end{array}$ & 57. & 130. & 0.0 & 4 & $0-15$ & $\mathrm{O}$ & $\begin{array}{l}10-20 \\
\text { years }\end{array}$ & Volume per quarter ${ }^{\mathrm{c} .}$ & $\begin{array}{l}\text { Bino (2000); CSBE } \\
\text { (2004); Faruqui and } \\
\text { Al-Jayyousi (2002); } \\
\text { Interview plumber }\end{array}$ \\
\hline Drill well & 10,300 & 13,800 & 5,400 & 1 & -- & $\mathrm{D}, \mathrm{I}, \mathrm{O}$ & $\begin{array}{l}10-20 \\
\text { years }\end{array}$ & $\begin{array}{l}\text { Price to license well } \\
\text { and drill to depths of } \\
60 \text { to } 200 \text { meters. }\end{array}$ & $\begin{array}{l}\text { Hadidi, pers. comm., } \\
2004 \text {; El-Halah, pers. } \\
\text { comm., } 2004\end{array}$ \\
\hline $\begin{array}{l}\text { Install in-home } \\
\text { water treatment }\end{array}$ & 210. & 330. & 140. & 4 & 0 to 0.7 & $\mathrm{D}$ & 3 years & $\begin{array}{l}\text { Input volume per day. } \\
\text { Excludes JD } 54 \text { - } 180 \\
\text { per year upkeep cost. }\end{array}$ & $\begin{array}{l}\text { Retail store } \\
\text { interviews }\end{array}$ \\
\hline \multicolumn{10}{|c|}{ Short-term actions } \\
\hline \multicolumn{10}{|c|}{ Take delivery through municipal network } \\
\hline $\begin{array}{l}\text { Up to } 20 \mathrm{~m}^{3} \text { per } \\
\text { quarter }\end{array}$ & -- & Infinity & 0.17 & \multirow{4}{*}{ I } & 1 & \multirow{4}{*}{$\mathrm{D}, \mathrm{I}, \mathrm{O}$} & 3 months & $\begin{array}{l}\text { Flat charge of JD } \\
3.47 .\end{array}$ & $\begin{array}{l}\text { LEMA (2004); WAJ } \\
(2004)\end{array}$ \\
\hline $\begin{array}{l}20-40 \mathrm{~m}^{3} \text { per } \\
\text { quarter }\end{array}$ & 0.18 & -- & -- & & 1 & & 3 months & $\begin{array}{l}\text { Constant price of JD } \\
0.18 / \mathrm{m}^{3}\end{array}$ & $\begin{array}{l}\text { LEMA (2004); WAJ } \\
(2004)\end{array}$ \\
\hline $\begin{array}{l}40-130 \mathrm{~m}^{3} \text { per } \\
\text { quarter }\end{array}$ & -- & 0.57 & 2.34 & & 1 & & 3 months & $\begin{array}{l}\text { Variable price from } \\
\text { quadratic formula }\end{array}$ & $\begin{array}{l}\text { LEMA (2004); WAJ } \\
(2004)\end{array}$ \\
\hline $\begin{array}{l}\text { Above } 130 \mathrm{~m}^{3} \mathrm{per} \\
\text { quarter }\end{array}$ & 1.24 & -- & -- & & 1 & & 3 months & $\begin{array}{l}\text { Constant price of JD } \\
1.24 / \mathrm{m}^{3}\end{array}$ & $\begin{array}{l}\text { LEMA (2004); WAJ } \\
(2004)\end{array}$ \\
\hline \begin{tabular}{|l|} 
Buy water from \\
water store
\end{tabular} & 46. & 50. & 40. & 5 & 1 & $\mathrm{D}$ & $\begin{array}{l}\text { day - } \\
\text { week }\end{array}$ & $\begin{array}{l}\text { Price includes delivery } \\
\text { to house }\end{array}$ & $\begin{array}{l}\text { Retail store } \\
\text { interviews }\end{array}$ \\
\hline Buy bottled water & 153. & 233. & 104. & 4 & 1 & $\mathrm{D}$ & day & $\begin{array}{l}\text { Purchase price at } \\
\text { store }\end{array}$ & $\begin{array}{l}\text { Purchases at mini- } \\
\text { markets }\end{array}$ \\
\hline $\begin{array}{l}\text { Buy water from } \\
\text { tanker truck }\end{array}$ & 2.40 & 4.30 & 1.50 & 5 & 1 & $\mathrm{I}, \mathrm{O}$ & week & $\begin{array}{l}\text { Generally requires } \\
\text { minimum } 6 \mathrm{~m}^{3} \\
\text { purchase }\end{array}$ & $\begin{array}{l}\text { LEMA (2004); Driver } \\
\text { interviews; observe } \\
\text { customer purchases }\end{array}$ \\
\hline $\begin{array}{l}\text { Borrow from } \\
\text { neighbor }\end{array}$ & -- & -- & -- & 4 & $<0.25$ & $\mathrm{I}$ & day & Never pay for water & $\begin{array}{l}\text { Iskandarani (2002); } \\
\text { survey responses }\end{array}$ \\
\hline $\begin{array}{l}\text { Draw water from } \\
\text { well }\end{array}$ & -- & -- & -- & 0 & -- & $\mathrm{D}, \mathrm{I}, \mathrm{O}$ & day & $\begin{array}{l}\text { Not available to urban } \\
\text { customers }\end{array}$ & Survey responses \\
\hline $\begin{array}{l}\text { Boil water in home } \\
\text { to drink }\end{array}$ & 3.42 & 0.44 & 11.80 & 4 & 1 & $\mathrm{D}$ & day & $\begin{array}{l}\text { Price estimated by } \\
\text { fuel cost to heat } 10 \text { to } \\
20 \text { teapots per day }\end{array}$ & Engineering estimate \\
\hline Store water & -- & -- & $\begin{array}{ll}- \\
-\end{array}$ & 0 & $1-42$ & $\mathrm{D}, \mathrm{I}, \mathrm{O}$ & week & $\begin{array}{l}\text { Volume per week }{ }^{\mathrm{c}} \\
\text { limited by storage. } \\
\text { Negligible costs. }\end{array}$ & Engineering estimate \\
\hline $\begin{array}{l}\text { Draw water from } \\
\text { storage }\end{array}$ & -- & -- & -- & 0 & $1-42$ & $\mathrm{D}, \mathrm{I}, \mathrm{O}$ & week & $\begin{array}{l}\text { Volume per week } \\
\text { limited by storage. } \\
\text { Excludes pump costs }\end{array}$ & Engineering estimate \\
\hline
\end{tabular}

\section{Notes:}

a. JD $1.00=$ \$US 1.41

b. Water use quality classifications: $\mathrm{D}=$ for drinking and cooking; I=indoor for washing and hygiene; $\mathrm{O}=$ outdoor for irrigating, livestock, and car washing

c. Water volume range represents absolute physical lower and upper limits (0 and 100th percentiles) 


\section{Table 4. Potential Actions to Reduce Household water Demands in Jordan}

\begin{tabular}{|c|c|c|c|c|c|c|c|c|c|}
\hline \multirow{2}{*}{$\begin{array}{l}\text { Water Management } \\
\text { Action }\end{array}$} & \multicolumn{4}{|c|}{ Price Quotes $^{\mathrm{a}}$} & \multirow{2}{*}{$\begin{array}{l}\text { Estimated } \\
\text { savings }^{b}\end{array}$} & \multirow{2}{*}{$\begin{array}{l}\text { Maximum } \\
\text { coverage }^{c}\end{array}$} & \multirow{2}{*}{ Uses $^{d}$} & \multirow{2}{*}{$\begin{array}{c}\text { Est. } \\
\text { lifespan }\end{array}$} & \multirow{2}{*}{ Information source(s) } \\
\hline & Average & Highest & Lowest & Num. & & & & & \\
\hline Long-term actions & (JD) & (JD) & (JD) & & $\left(m^{3}\right.$ per year) & (Percent) & & & \\
\hline Retrofit showerheads & 58. & 150. & 5. & 3 & $0.0-107$ & $82 \%$ & $\mathrm{I}$ & 5 years & $\begin{array}{l}\text { WEPIA (2000a); } \\
\text { interview retail store } \\
\text { owners }\end{array}$ \\
\hline Retrofit kitchen faucets & 3.0 & 3.5 & 2.0 & 3 & $2.1-93$ & $93 \%$ & $\mathrm{D}, \mathrm{I}$ & 5 years & $\begin{array}{l}\text { WEPIA (2000a); } \\
\text { interview retail store } \\
\text { owners }\end{array}$ \\
\hline Retrofit bath faucets & 3.0 & 3.5 & 2.0 & 3 & $0.0-19$ & $90 \%$ & 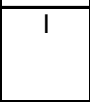 & 5 years & $\begin{array}{l}\text { WEPIA (2000a); } \\
\text { interview retail store } \\
\text { owners }\end{array}$ \\
\hline $\begin{array}{l}\text { Install toilet dual-flush } \\
\text { mechanisms }\end{array}$ & 14. & 25. & 4. & 4 & $0.0-118$ & $70 \%$ & 1 & 5 years & $\begin{array}{l}\text { IdRC (2004); interview } \\
\text { store owners }\end{array}$ \\
\hline Retrofit toilets & 83. & 165. & 28. & 16 & $0.0-73.5$ & $84 \%$ & 1 & 10 years & $\begin{array}{l}\text { IdRC(2004); Interview } \\
\text { store owners }\end{array}$ \\
\hline \begin{tabular}{|l|} 
Install water efficient \\
semi-automatic \\
laundry machine \\
\end{tabular} & 137. & 290. & 80. & 4 & $0.0-30.3$ & $84 \%$ & 1 & 5 years & $\begin{array}{l}\text { IdRC (2004); interview } \\
\text { store owners }\end{array}$ \\
\hline $\begin{array}{l}\text { Install water efficient } \\
\text { automatic laundry } \\
\text { machine }\end{array}$ & 552. & 620. & 370. & 12 & $0.0-6.3$ & $68 \%$ & $\mathrm{I}$ & 5 years & $\begin{array}{l}\text { IdRC (2004); interview } \\
\text { store owners }\end{array}$ \\
\hline \begin{tabular}{|l} 
Install low-water \\
consuming landscape
\end{tabular} & 2,100 & 3,500 . & 300. & 1 & $0.0-46.3$ & $11 \%$ & $\mathrm{O}$ & 10 years & CSBE (2004) \\
\hline $\begin{array}{l}\text { Install drip irrigiation } \\
\text { system }\end{array}$ & 18. & 20. & 15. & 4 & $0.0-18.0$ & $10 \%$ & $\mathrm{O}$ & 5 years & \begin{tabular}{|l} 
Interveiw retail store \\
owners and employees
\end{tabular} \\
\hline $\begin{array}{l}\text { Install spray nozzle on } \\
\text { hoses }\end{array}$ & 3.0 & 4.0 & 1.0 & 5 & $0.0-7.0$ & $12 \%$ & $\mathrm{O}$ & 2 years & $\begin{array}{l}\text { Interveiw retail store } \\
\text { owners and employees }\end{array}$ \\
\hline Install carpet on floors & 3,150 . & 6,000 & 300. & 2 & $4.0-42.5$ & $100 \%$ & $\mathrm{I}$ & 5 years & Interview store owners \\
\hline \begin{tabular}{|l|} 
Install pressure \\
reducing valve
\end{tabular} & 35. & 40. & 30. & 1 & $0.0-20.7$ & $14 \%$ & $\mathrm{I}, \mathrm{O}$ & 5 years & \begin{tabular}{|l} 
Interview with pipe \\
engineers
\end{tabular} \\
\hline Short-term actions & (JD) & (JD) & (JD) & & $\left(\mathrm{m}^{3}\right.$ per week $)$ & (Percent) & & & \\
\hline $\begin{array}{l}\text { Install bags or bottles } \\
\text { in toilets }\end{array}$ & -- & -- & -- & -- & $0.1-0.4$ & $100 \%$ & $\mathrm{I}$ & $\begin{array}{c}1-6 \\
\text { months }\end{array}$ & \\
\hline Find and fix leaks & 5. & 8. & 2. & 4 & & $100 \%$ & $\mathrm{I}, \mathrm{O}$ & day & $\begin{array}{l}\text { Interview plumber \& } \\
\text { households }\end{array}$ \\
\hline $\begin{array}{l}\begin{array}{l}\text { Reduce landscape } \\
\text { irrigation }\end{array} \\
\end{array}$ & -- & -- & -- & & $0.0-0.2$ & $12 \%$ & $\mathrm{O}$ & week & \\
\hline $\begin{array}{l}\text { Turn off faucets while } \\
\text { washing }\end{array}$ & -- & -- & -- & -- & $0.0-0.4$ & $75 \%$ & 1 & day & \\
\hline Partially open faucet & -- & -- & -- & -- & $0.0-0.4$ & $88 \%$ & 1 & minutes & \\
\hline Reduce shower length & -- & -- & -- & -- & $0.0-19.8$ & $77 \%$ & $\mathrm{I}$ & minutes & \\
\hline $\begin{array}{l}\text { Reduce shower-taking } \\
\text { frequency }\end{array}$ & -- & -- & -- & -- & $0.0-17.1$ & $42 \%$ & $\mathrm{I}$ & week & \\
\hline \begin{tabular}{|l|} 
Reduce laundry- \\
washing frequency
\end{tabular} & -- & -- & -- & -- & $0.0-0.3$ & $100 \%$ & 1 & week & \\
\hline $\begin{array}{l}\text { Sweep rather than } \\
\text { wash floors }\end{array}$ & -- & -- & -- & -- & $0.1-0.8$ & $100 \%$ & $\mathrm{I}$ & day & \\
\hline Wash car with buckets & 2.5 & 5.0 & 0.0 & 2 & $0.0-15$ & $74 \%$ & $\mathrm{O}$ & week & \\
\hline Wash car at gas & 1.5 & 2.0 & 1.0 & 3 & $0.0-14.5$ & $74 \%$ & $\mathrm{O}$ & week & Household interviews \\
\hline
\end{tabular}
Notes:

a. JD $1.00=\$ \cup S 1.41$

b. Range represents estimated 10th and 90th percentiles for population of Amman households based on varying household geographical, technological, and behavioral factors

c. Percent of households estimated to save water by adopting the action

d. Water use classes: $\mathrm{D}=$ drinking and cooking; I=indoor for washing and hygiene; $\mathrm{O}=$ outdoor for irrigating, livestock, and wash cars. 


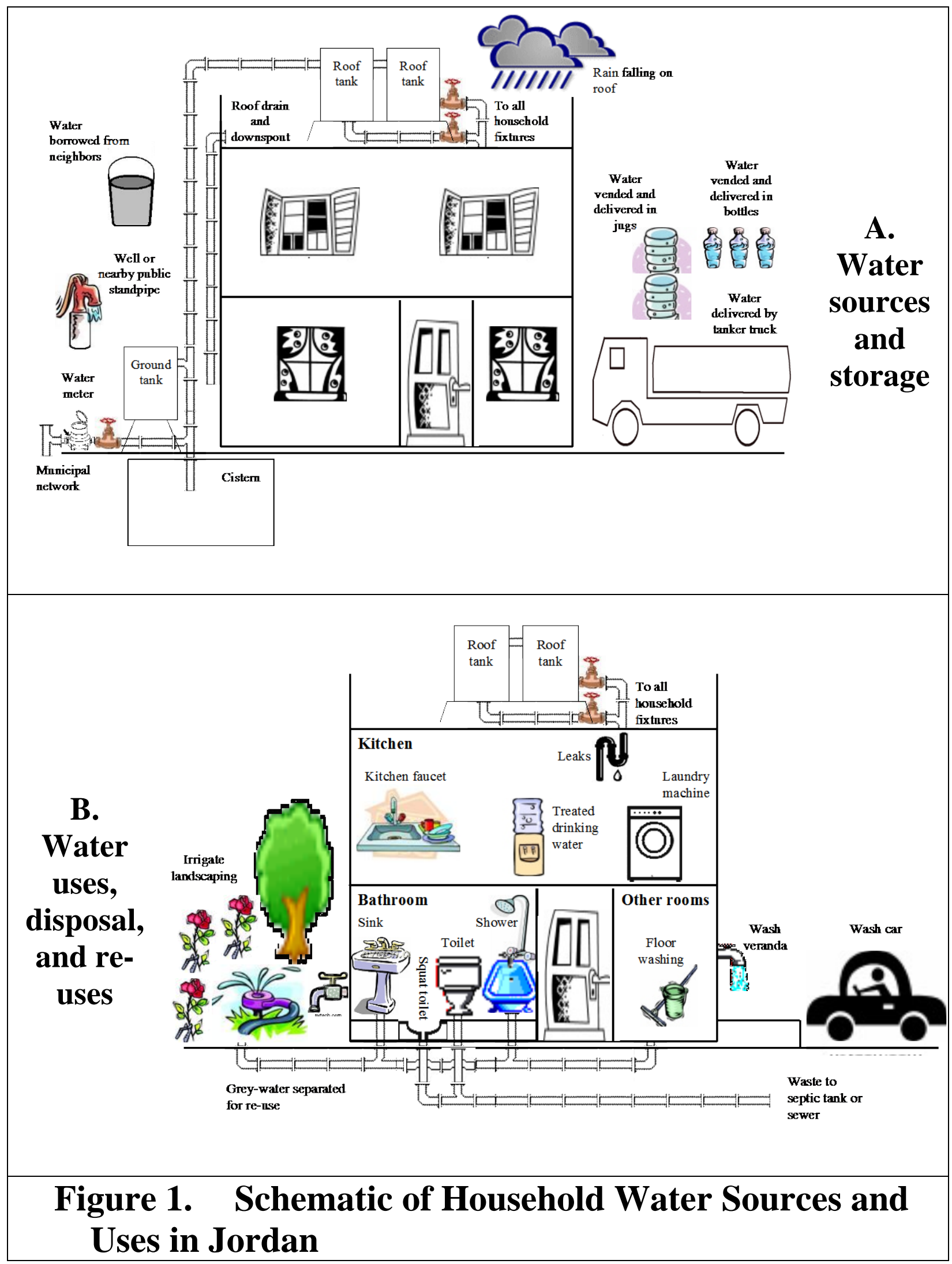

